[Agr. Biol. Chem., Vol. 34, No. 1, p. 115 121, 1970]

\title{
Synthesis of Compounds with Juvenile Hormone Activity
}

\author{
Part V. Some $\beta$-Bisabolene Derivatives ${ }^{\dagger}$ \\ By Kenji Mori and Masanao Matsui \\ Department of Agricultural Chemistry, Faculty of Agriculture, \\ University of Tokyo, Bunkyo-ku, Tokyo 113 \\ Received June 25, 1969
}

\begin{abstract}
Some $\beta$-bisabolene derivatives, III, XX, XXVII and XXVIII, were synthesized and shown to possess the juvenile hormone activity.
\end{abstract}

Bisabolene-type compounds are known to possess the juvenile hormone activity as evidenced by juvabione (I), ${ }^{1 \sim 31}$ dehydrojuvabione (II), ${ }^{2,4)}$ ar-juvabione ${ }^{36)}$ and other analogues. ${ }^{5 \sim 71}$

In continuation of our synthetic work on these compounds, ${ }^{3 a, 4,7)}$ we planned the synthesis of 2-(4'-carbomethoxycyclohex-3'-enyl)6-methylhepta-1, 5-diene (III) and its derivatives. Although the parent hydrocarbon, $\beta$ bisabolene (IV), ${ }^{8 \sim 10}$ and the related alcohol,

$\dagger$ Part IV, K. Mori, M. Ohki, M. Matsui and W. S. Bowers, Agr. Biol. Chem., 33, 1792 (1969).

1) W.S. Bowers, H. M. Fales, M. J. Thompson and E. C. Uebel, Science, 154, 1020.(1966).

2) V. Cěrný, L. Dolejš̌, L. Lábler, F. Šorm and K. Sláma, Tetrahedron Letters, 1967, 1053; Idem., Coll. Czechoslov. Chem. Commun., 32, 3926 (1967).

3) a) K. Mori and M. Matsui, Tetrahedron Letters, 1967, 2515; Idem., Tetrahedron, 24, 3127 (1968).

b) K.S. Ayyar and G.S. Krishna Rao, Tetrahedron Letters, 1967, 4677; Idem., Canad. J. Chem., 46, 1467 (1968).

c) B. A. Pawson, H. C. Cheung, S. Gurbaxanc and G. Saucy, Chem. Commun., 1968, 1057.

d) A. J. Birch, P. L. MacDonald and V. H. Powell, Tetrahedron Letters, $1969,351$.

4) K. Mori and M. Matsui, ibid., 1967, 4853.

5) K. Sláma, M. Suchý and F. Sorm, Biol. Bull., 134, 154 (1968).

6) M. Suchý, K. Sláma and F. Šrm, Science, 162, 582 (1968).

7) K. Mori, T. Miyake, I. Yoshimura and M. Matsui, Agr. Biol. Chem., 33, 1745 (1969).

8) O.P. Vig, K. L. Matta, G. Singh and I. Raj, J. Indian Chem. Soc., 43, 27 (1966).

9) A. Manjarrez and A. Guzman, J. Org. Chem., 31, 348 (1966).

10) O. P. Vig, J. P. Salota, B. Vig and B. Ram, Indian J. Chem., 5, 475 (1967). lanceol $(\mathrm{V})^{10,111}$ are found in nature and have been synthesized, neither the ester (III) nor the corresponding alcohol (XXV) has been isolated as a natural product. The molecule III was dissected into four synthons-A, B, C and $D$. The connection of the four in their alphabetical order afforded the desired product.

The starting material for the synthon $\mathrm{A}$ was the known trans-4-hydroxycyclohexane-1-carboxylic acid (VI). ${ }^{12}$ Its hydroxyl group was protected by acetylation. The resulting acetoxy acid (VII) was converted into the corresponding acyl chloride (VIII). This was treated with an organocadmium or a Grignard reagent prepared from 4-methylpent-3-enyl bromide ${ }^{131}$ (the synthon B) to give a ketone (IX). Its conversion into an isomeric acetoxy ketone (XV) was accomplished in the following manner. ${ }^{\text {cf 14l }}$ A ketol (X), obtained by alkaline hydrolysis of IX, was treated with dihydropyran and $p$-toluenesulfonic acid to give a tetrahydropyranyl ether (XI). Its borohydride reduction yielded an alcohol (XII). The corresponding acetate (XIII) was sub-

11) A. Manjarrez, T. Riost and A. Guzman, Tetrahedron, 20, 333 (1964).

12) L. N. Owen and P. A. Robins, J. Chem. Soc., $1949,330$.

13) M. Julia, S. Julia and R. Guégan, Bull. Soc. chim. France, 1960, 1072.

14) F. Sondheimer, M. Velasco and G. Rosenkranz, J. Am. Chem. Soc., 77, 5673 (1955). 
116

K. Mort and M. Matsu
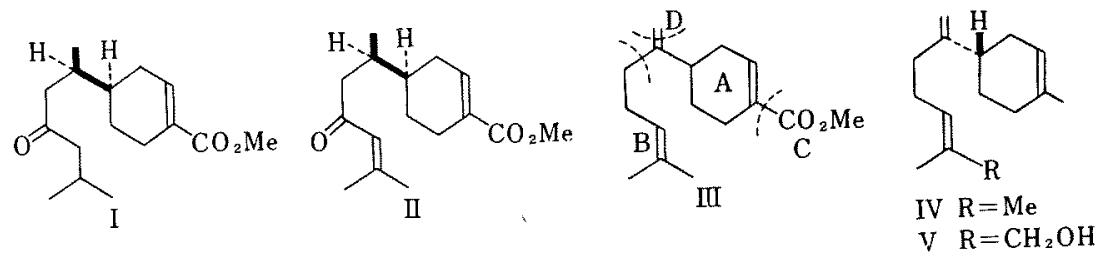

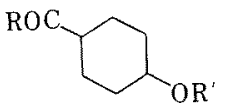

VI $\mathrm{R}=\mathrm{OH} \quad \mathrm{R}^{\prime}=\mathrm{H}$

VII $\mathrm{R}=\mathrm{OH} \mathrm{R}^{\prime}=\mathrm{Ac}$

VIII $\mathrm{R}=\mathrm{Cl} \quad \mathrm{R}^{\prime}=\mathrm{Ac}$
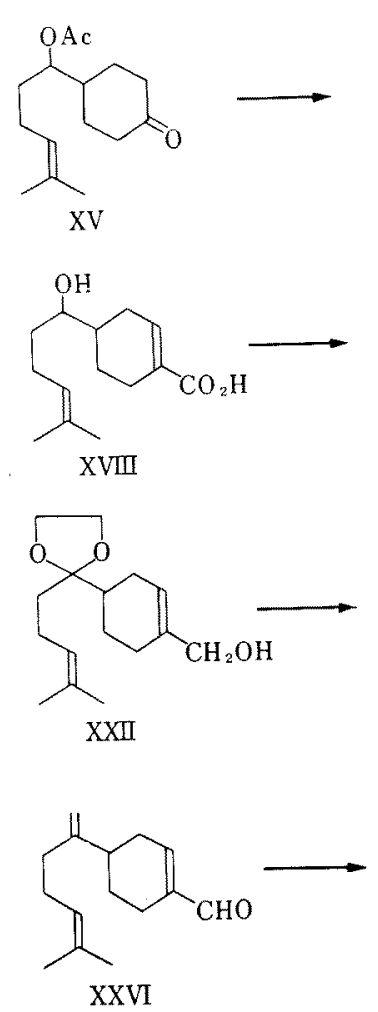

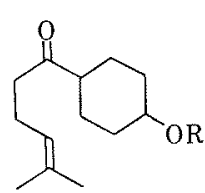

IX $\mathrm{R}=\mathrm{Ac}$

X $\mathrm{R}=\mathrm{H}$

$\mathrm{XI} \quad \mathrm{R}=\mathrm{O}_{\mathrm{O}}$
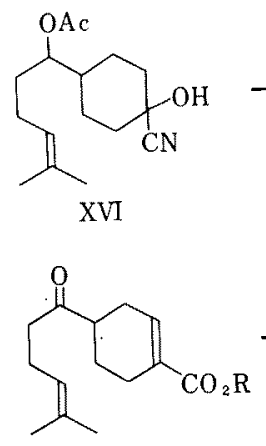

$\mathrm{XIX} \mathrm{R}=\mathrm{H}$

XX $\mathrm{R}=\mathrm{Me}$

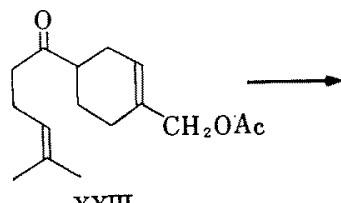

XXIII

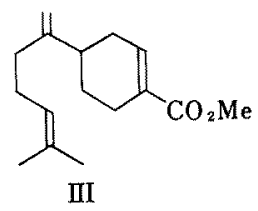

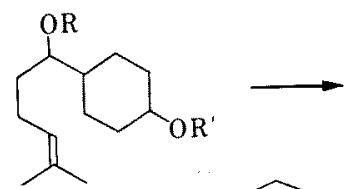

XII $R=H \quad R^{\prime}=C_{O}$

XIII $R=A c R^{\prime}=\overbrace{0}$

$\mathrm{XIV} R=A c \cdot R^{\prime}=\mathrm{H}$
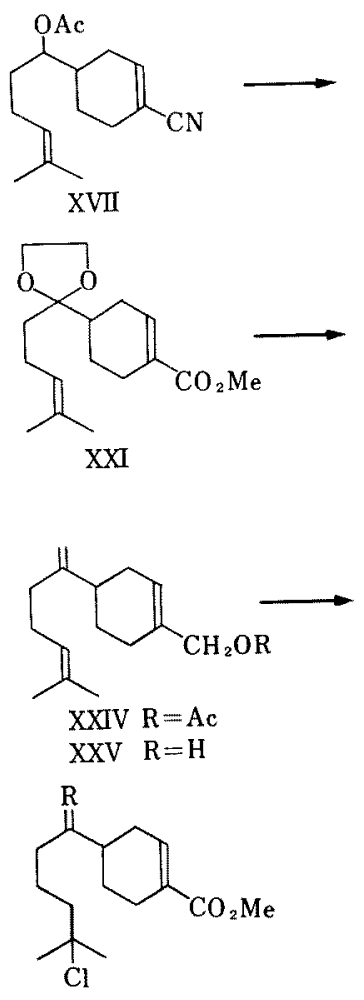

XXVII $\mathrm{R}=\mathrm{O}$

XXVIII $\mathrm{R}=<\mathrm{Cl}$ 
mitted to acid hydrolysis followed by Jones oxidation $^{151}$ to afford the desired acetoxy ketone (XV) via a diol monoacetate (XIV).

The third synthon, in the form of hydrogen cyanide, was attatched to the molecule to give a cyanohydrin (XVI). This was treated with phosphorus oxychloride and pyridine to afford an unsaturated nitrile (XVII). Its alkaline hydrolysis gave a hydroxy acid (XVIII). This was oxidized with the Jones reagent to give a crystalline keto acid (XIX). The corresponding methyl ester (XX) was converted into a ketal (XXI). Its reduction with lithium aluminum hydride gave an alcohol (XXII). A keto acetate (XXIII) was obtained by acetylation and acid hydrolysis of XXII.

The fourth synthon was then attatched to the molecule by the Wittig reaction ${ }^{161}$ to give an acetate (XXIV). The corresponding alcohol (XXV) was oxidized with manganese dioxide to give an aldehyde (XXVI). This was converted into the final product (III) by the method of Corey and his co-workers. ${ }^{17}$

Since some chlorinated esters were known to possess high juvenile hormone activity, ${ }^{5,181}$ the esters XX and III were treated with hydrogen chloride to give the chlorinated esters, XXVII and XXVIII, respectively.

The biological activity of the four synthetic products, III, XX, XXVII and XXVIII, was tested on newly molted last instar nymphs of Pyrrhocoris apterus L. by the courtesy of Dr. W.S. Bowers of USDA Agricultural Research Service. The dichloro ester XXVIII was the most active and might be compared to our synthetic juvabione $(\mathrm{I})^{3 a)}$ in activity, while III and XXVII were slightly active. The keto ester XX exhibited intermediate activity. Thus all of the four compounds were shown

15) A. Bowers, T. G. Halsall, E. R. H. Jones and A. J. Lewis, J. Chem. Soc., 1953, 2548.

16) R. Greenwald, M. Chaykovsky and E. J. Corey, J. Org. Chem., 28, 1128 (1963).

17) E. J. Corey, N. W. Gilman and B. E. Ganem, J. Am. Chem. Soc., 90, 5616 (1968).

18) M. Romaňuk, K. Sláma and F. Šorm, Proc. Nat Acad. Sci. U.S.A., 57, 349 (1967). to possess the juvenile hormone activity.

\section{EXPERIMENTAL}

All $\mathrm{mp}$ and bp were uncorrected. IR spectra refer to Nujol mulls for solid samples and films for liquids. NMR spectra were recorded at $100 \mathrm{MHz}$ in $\mathrm{CCl}_{4}$ with TMS as an internal standard unless otherwise stated.

trans-4-Acetoxycyclohexane-1-carboxylic acid (VII). Acetic anhydride $(250 \mathrm{ml})$ was added to a solution of trans-4-hydroxycyclohexane-1-carboxylic acid (VI, $156 \mathrm{~g})$ in pyridine $(800 \mathrm{ml})$. The mixture was left to stand at room temp. for 2 days, concentrated in vacuo and diluted with ether. The ether solution was washed with dil $\mathrm{HCl}$, dried $\left(\mathrm{MgSO}_{4}\right)$ and concentrated to give a crystalline product (VII, $50 \mathrm{~g}$ ). The oily mother liquor was dissolved in THF $(300 \mathrm{ml})$. The solution was stirred with $\mathrm{NaHCO}_{3}$ aq $(100 \mathrm{~g}$ in $500 \mathrm{ml})$ for $1 \mathrm{hr}$ at room temp and $20 \mathrm{~min}$ under reflux. After cooling, the mixture was extracted with ether to remove neutral impurities. The aqueous layer was acidified with dil $\mathrm{HCl}$ and extracted with EtOAc. The extract was washed with $\mathrm{NaCl}$ aq, dried $\left(\mathrm{MgSO}_{4}\right)$ and concentrated to give $44 \mathrm{~g}$ of VII. The total amount of VII was $94 \mathrm{~g}(46 \%)$. Recrystallization from EtOAc gave elongated prisms, mp $133 \sim 134^{\circ} \mathrm{C}$. Anal. Found: C, 58.73; H, 7.84. Calcd. for $\mathrm{C}_{9} \mathrm{H}_{14} \mathrm{O}_{4}$ : C, 58.05; H, 7.58\%. $\nu_{\max } \sim 3200-\sim 2600,1740,1705$, $1266,1250,1235,1045,1024,745 \mathrm{~cm}^{-1} ; \delta 2.05(3 \mathrm{H}$, s), 4.75 ( $1 \mathrm{H}$, broad) ppm.

trans-4-Acetoxycyclohexane-1-carboxylic acid chloride $(V I I I)$. A suspension of VII $(18.6 \mathrm{~g})$ in benzene $(60$ $\mathrm{ml}$ ) was mixed with $\mathrm{SOCl}_{2}(40 \mathrm{ml})$ and heated under reflux for $30 \mathrm{~min}$. The solvent was removed in vacuo to give an oily VIII ( $20.5 \mathrm{~g}$, quantitative). This was employed for the next reaction without further purification.

4-Methylpent-3-enyl 4'-acetoxycyclohexyl ketone (IX). A Grignard reagent was prepared from 4-methylpent3-enyl bromide $(20 \mathrm{~g})$ and $\mathrm{Mg}(2.9 \mathrm{~g})$ in ether $(100 \mathrm{ml})$. Dry $\mathrm{CdCl}_{2}(22 \mathrm{~g})$ was added to the solution and the mixture was stirred and heated under reflux for 45 min. Ether was distilled off from the mixture and the residue was diluted with dry benzene $(150 \mathrm{ml})$. To this organo-cadmium reagent, VIII $(20.5 \mathrm{~g})$ in benzene $(50 \mathrm{ml})$ was added dropwise. After the addition, the mixture was stirred and heated under reflux for $2 \mathrm{hr}$, left to stand overnight at room temp and 
poured into ice-cooled dil $\mathrm{H}_{2} \mathrm{SO}_{4}$. The benzene layer was separated and the aqueous layer was extracted with ether. The combined organic soln was washed with water, $5 \% \mathrm{Na}_{2} \mathrm{CO}_{3}$ aq, and $\mathrm{NaCl}$ aq, $\operatorname{dried}\left(\mathrm{MgSO}_{4}\right)$ and concentrated. The residue was distilled in vacuo to give $13.2 \mathrm{~g}(51 \%)$ of IX, bp $130 \sim 150^{\circ} \mathrm{C} / 1.0 \mathrm{~mm}$. An analytical sample boiled at $144 \sim 145^{\circ} \mathrm{C} / 0.6 \mathrm{~mm}$; $n_{\mathrm{D}}^{19}$ 1.4765. Anal. Found: C, 68.93; H, 9.02. Calcd. for $\mathrm{C}_{15} \mathrm{H}_{24} \mathrm{O}_{3} ; \mathrm{C}, 71.39 ; \mathrm{H}, 9.59 \%$, $\nu_{\max } 1738,1718$, 1626 (due to impurities), $1240,1040 \mathrm{~cm}^{-1} ; \delta 1.62(3 \mathrm{H}$, s), $1.66(3 \mathrm{H}, \mathrm{s}), 1.96(3 \mathrm{H}, \mathrm{s}), 4.62(1 \mathrm{H}$, broad $), 5.05$ ( $1 \mathrm{H}$, broad) ppm. The sample could not be purified by distillation alone. No attempt was made to obtain pure IX by chromatographic purification.

4-Methylpent-3-enyl 4'-hydroxycyclohexyl ketone (X). a) A soln of IX (232 g) in $\mathrm{MeOH}(480 \mathrm{ml})$ was mixed with $\mathrm{KOH}$ aq. $(80 \mathrm{~g}$ in $200 \mathrm{ml}$ ) and the mixture was left to stand at room temp. for 2 days. After removal of $\mathrm{MeOH}$ in vacuo, the residue was diluted with water and extracted with ether. The extract was washed with water and $\mathrm{NaCl}$ aq, dried $\left(\mathrm{MgSO}_{4}\right)$ and concentrated. The residue was fractionally distilled in vacuo to give $120 \mathrm{~g}(639)$ of $\mathrm{X}$, bp $145 \sim 150^{\circ} \mathrm{C} / 0.1 \mathrm{~mm}$. An analytical sample boiled at $144 \sim 146^{\circ} \mathrm{C} / 1.0 \mathrm{~mm}, n_{\mathrm{D}}^{20}$ 1.4924. Anal. Found: C, 73.98; H, 10.24. Calcd. for $\mathrm{C}_{13} \mathrm{H}_{22} \mathrm{O}_{2}$ : C, $74.24 ; \mathrm{H}, 10.54 \% . \quad \nu_{\max } \sim 3400,1708$, $1622,1065 \mathrm{~cm}^{-1} ; \delta 1.60(3 \mathrm{H}, \mathrm{s}), 1.66(3 \mathrm{H}, \mathrm{s}), \sim 3.35$ ( $1 \mathrm{H}$, broad), 3.95 ( $1 \mathrm{H}$, broad), $5.04(1 \mathrm{H})$ ppm. b) A Grignard reagent prepared from 4-methylpent-3-enyl bromide $(98 \mathrm{~g}$ ) and $\mathrm{Mg}(14.5 \mathrm{~g}$ ) in ether $(400 \mathrm{ml}$ ) was added to a stirred and ice-cooled soln of VIII (from $94 \mathrm{~g}$ of VII) in ether $(120 \mathrm{ml})$ containing $\mathrm{Cu}_{2} \mathrm{Cl}_{2}(0.4 \mathrm{~g})$. The stirring was continued for $2 \mathrm{hr}$ at $0 \sim 5^{\circ} \mathrm{C}$ and then for $3 \mathrm{hr}$ at room temp. The mixture was left to stand overnight at room temp and then poured into ice-cooled dil HCl. The ether layer was separated and the aqueous layer was extracted with ether. The extract was washed with $\mathrm{NaCl}$ aq, dried $\left(\mathrm{MgSO}_{4}\right)$ and concentrated. The oily residue $(110 \mathrm{~g})$ was dissolved in $\mathrm{MeOH}(240 \mathrm{ml})$ and mixed with $\mathrm{KOH}$ aq $(40 \mathrm{~g}$ in $120 \mathrm{ml})$. The mixture was left to stand overnight at room temp. Subsequent treatments as described in a) gave $32 \mathrm{~g}(30,6)$ of $\mathrm{X}$, bp $145 \sim 155^{\circ} \mathrm{C} /$ $0.1 \mathrm{~mm}$.

4-Methylpent-3-enyl 4'-tetrahydropyranyloxycyclohexyl ketone $(X I)$. A soln of X (115 g) in dry benzene (1 liter) was mixed with dihydropyran $(100 \mathrm{ml})$ and $p-\mathrm{TsOH}$ $(1 \mathrm{~g})$ and left to stand overnight at room temp. The mixture was washed with $\mathrm{K}_{2} \mathrm{CO}_{3}$ aq and sat $\mathrm{NaCl} a q$, dried $\left(\mathrm{MgSO}_{4}\right)$ and concentrated in vacuo to give crude oily XI (195 g) contaminated with some dihydropyran. The IR spectrum of the oil exhibited no $\mathrm{OH}$ absorption.

1-(4'-Tetrahydropyranyloxycyclohexy)-5-methylhex-4-en-1ol $(X I I)$. A soln of XI $(195 \mathrm{~g})$ in $95 \% \mathrm{EtOH}(600$ $\mathrm{ml})$ was mixed with $\mathrm{NaBH}_{4}(10 \mathrm{~g})$ and $\mathrm{KOH}$ aq $(0.1 \mathrm{~g}$ in $5 \mathrm{ml})$. The mixture was left to stand overnight at room temp, concentrated in vacuo, diluted with water and extracted with ether. The extract was washed with water and sat $\mathrm{NaCl}$ aq, dried $\left(\mathrm{MgSO}_{4}\right)$ and concentrated to give crude oily XII $(190 \mathrm{~g})$ with no carbonyl absorption in its IR spectrum.

1-(4'-Tetrahydropyranyloxycyclohexyl)-1-acetoxy-5-methylhex-4-ene $(X I I I)$. Acetic anhydride $(300 \mathrm{ml})$ was added to a soln of XII $(190 \mathrm{~g})$ in pyridine $(300 \mathrm{mI})$. The mixture was left to stand at room temp for 2 days and then concentrated in vacuo to give an oil (ca. $195 \mathrm{~g}$ ) with no hydroxyl absorption in its IR spectrum.

1-(4'-Hydroxycyclohe $x y l)-1$-acetoxy -5 - methylhex-4-ene $(X I V)$. A soln of XIIII (ca. 195 g) in 95\% EtOH $(300 \mathrm{ml})$ was mixed with $5 \% \mathrm{HCl}(170 \mathrm{ml})$. After $3 \mathrm{hr}$ at room temp the mixture was concentrated in vacuo, diluted with water and extracted with ether. The ether soln was washed with water, $\mathrm{NaHCO}_{3}$ aq and sat $\mathrm{NaCl}$ aq, dried $\left(\mathrm{MgSO}_{4}\right)$ and concentrated. The residue was distilled in vacuo to give $114 \mathrm{~g}(85 \%$ from X) of XIV, bp $150 \sim 160^{\circ} \mathrm{C} / 0.08 \mathrm{~mm}$. An analytical sample boiled at $150 \sim 155^{\circ} \mathrm{C} / 1.5 \mathrm{~mm}, n_{\mathrm{D}}^{19} 1.4848$. Anal. Found; C, 71.40; H, 10.56. Calcd. for $\mathrm{C}_{15} \mathrm{H}_{26} \mathrm{O}_{3} ; \quad \mathrm{C}, 70.83 ; \mathrm{H}, 10.30 \%$. $\nu_{\max } 3400,1738$, $1240,1045,1015 \mathrm{~cm}^{-1} ; \delta 1.60(3 \mathrm{H}, \mathrm{s}), 1.66(3 \mathrm{H}, \mathrm{s})$, 1.98 ( $3 \mathrm{H}, \mathrm{s}), 3.35$ (1 $\mathrm{H}$, broad), 3.60 ( $1 \mathrm{H}$, broad), 4.66 ( $1 \mathrm{H}$, broad), 5.02 ( $1 \mathrm{H}$, broad) ppm.

1-(4'-Oxocyclohexyl)-1-acetoxy-5-methylhex-4-ene

To a soln of XIV $(110 \mathrm{~g})$ in acetone (1.2 liters) was added Jones reagent $(100 \mathrm{ml})$ at $0 \sim 5^{\circ} \mathrm{C}$ during $30 \mathrm{~min}$. After $30 \mathrm{~min} \mathrm{MeOH}$ was added to destroy the excess oxidant. The mixture was concentrated in vacuo. The residue was diluted with water and extracted with ether. The ethereal soln was washed with water, $\mathrm{NaHCO}_{3}$ aq and sat $\mathrm{NaCl}$ aq, dried $\left(\mathrm{MgSO}_{4}\right)$ and concentrated in vacuo. The residue was distilled in vacuo to give $81 \mathrm{~g}(74 \%)$ of $\mathrm{XV}$, bp $135 \sim 150^{\circ} \mathrm{C} / 0.08$ $\mathrm{mm}$. An analytical sample boiled at $140 \sim 144^{\circ} \mathrm{C} /$ $0.08 \mathrm{~mm}, n_{\mathrm{D}}^{20} 1.4775$. Anal. Found; C, $71.71 ; \mathrm{H}, 9.54$. Calcd. for $\mathrm{C}_{15} \mathrm{H}_{24} \mathrm{O}_{5}: \quad 0,71.39 ; \mathrm{H}, 9.59 \%$. $\nu_{\max } 1728$, 
$1240,1015 \mathrm{~cm}^{-1} ; \delta 1.58(3 \mathrm{H}, \mathrm{s}), 1.67(3 \mathrm{H}, \mathrm{s}), 2.00$ ( $3 \mathrm{H}, \mathrm{s}), 4.67$ ( $1 \mathrm{H}$, broad), 5.04 ( $\mathrm{l} \mathrm{H}$, broad) ppm.

\section{1-(4'-Cyano-4'-hydroxycyclohexyl)-1-acetoxy-5-methylhex-} 4-ene $(X V I)$. To a stirred and ice-cooled soln of XV $(81 \mathrm{~g})$ in $95 \% \mathrm{EtOH}(430 \mathrm{ml})$ powdered $\mathrm{KCN}(70 \mathrm{~g})$ was added followed by $\mathrm{AcOH}(76 \mathrm{ml})$. After the addition, the mixture was stirred for $30 \mathrm{~min}$ at $0 \sim$ $5^{\circ} \mathrm{C}$ and then for $30 \mathrm{~min}$ at $40 \sim 50^{\circ} \mathrm{C}$. The excess HCN was removed in vacuo after the addition of $2 \sim$ 3 drops of conc HCl. The mixture was diluted with water and extracred with ether. The ether extract was washed with dil $\mathrm{HCl}$ and sat $\mathrm{NaCl}$ aq, dried $\left(\mathrm{MgSO}_{4}\right)$ and concentrated to give $90 \mathrm{~g}$ of crude oily XVI, $\nu_{\max } \sim 3400,2270(w), 1720,1690,1240,1050 \mathrm{~cm}^{-1}$. This was employed for the next reaction without further purification.

1-(4'-Cyanocyclohex-3'-enyl)-1-acetoxy-5-methylhex-4-ene (XVII). To an ice-cooled soln of XVI (90 g) in pyridine $(360 \mathrm{ml})$ was added $\mathrm{POCl}_{3}(90 \mathrm{~g})$. The darkcolored mixture was left for 2 days at room temp, heated under reflux for $30 \mathrm{~min}$ and finally poured into ice-water containing conc $\mathrm{HCl}(600 \mathrm{ml})$. The mixture was extracted with ether. The ethereal soln was washed with dil $\mathrm{HCl}$, water, $\mathrm{NaHCO}_{3}$ aq and sat $\mathrm{NaCl} \mathrm{aq}$, dried $\left(\mathrm{MgSO}_{4}\right)$ and concentrated. The residue was distilled in vacuo to give $69 \mathrm{~g}$ (83\% from $\mathrm{XV}$ ) of XVII, bp $140 \sim 160^{\circ} \mathrm{C} / 1.5 \mathrm{~mm}$. An analytical sample boiled at $145^{\circ} \mathrm{C} / 0.08 \mathrm{~mm}, n_{\mathrm{D}}^{28} 1.4902$. Anal. Found: $\mathrm{C}, 73.97 ; \mathrm{H}, 9.13 ; \mathrm{N}, 5.11$. Calcd. for $\mathrm{C}_{16} \mathrm{H}_{23} \mathrm{O}_{2} \mathrm{~N}$ : C, 73.53; H, 8.87; N, 5.36\%. $\nu_{\max } 2200$, $1742,1648,1605,1240,1015 \mathrm{~cm}^{-1} ; \delta 1.55(3 \mathrm{H}, \mathrm{s}), 1.65$ $(3 \mathrm{H}, \mathrm{s}), 1.98(3 \mathrm{H}, \mathrm{s}), 4.70(1 \mathrm{H}$, broad $), 5.00(1 \mathrm{H}$, broad), 6.52 (1 $\mathrm{H}$, broad) ppm.

1 -(4'-Carboxycyclohex $-3^{\prime}$-enyl) -5-methylhex-4-en-1-ol (XVIII). A soln of the crude XVII $(69 \mathrm{~g})$ in diethylene glycol $(300 \mathrm{ml})$ was mixed with $\mathrm{KOH}$ aq $(80 \mathrm{~g}$ in $250 \mathrm{ml}$ ) and the mixture heated under reflux for 42 hr. After cooling, the mixture was diluted with water and extracted with ether to remove neutral impurities. The alkaline aqueous layer was acidified with conc $\mathrm{HCl}(170 \mathrm{ml})$ and extracted with ether. The ethereal soln was washed with water and sat $\mathrm{NaCl} \mathrm{aq}$, dried $\left(\mathrm{MgSO}_{4}\right)$ and concentrated to give oily crude XVIII $(63 \mathrm{~g}, 99 \%)$, $\nu_{\max }($ film $) \sim 3400, \sim 3200-\sim$ $2600,1690,1645 \mathrm{~cm}^{-1}$. This was employed for the next step without further purification.

4-Methylpent-3-enyl 4'-carboxycyclohex-3'-enyl ketone $(X I X)$. To a soln of XVIII $(63 \mathrm{~g})$ in acetone $(500 \mathrm{ml})$ was added Jones reagent $(60 \mathrm{ml})$ at $0 \sim 5^{\circ} \mathrm{C}$. After $30 \mathrm{~min} \mathrm{MeOH}$ was added to destroy the excess oxidant. The mixture was concentrated in vacuo. The residue was diluted with water and extracted with ether. The ethereal soln was washed with water and sat $\mathrm{NaCl}$ aq, dried $\left(\mathrm{MgSO}_{4}\right)$ and concentrated. The residue was distilled in vacuo to give $43 \mathrm{~g}(68 \%)$ of $\mathrm{XIX}$, bp $190 \sim 200^{\circ} \mathrm{C} / 1.5 \mathrm{~mm}$. An analytical sample boiled at $165 \sim 168^{\circ} \mathrm{C} / 0.08 \mathrm{~mm}, n_{\mathrm{D}}^{32} 1.5080 ;$ Anal. Found: C, 70.88; $\mathrm{H}, 8.80$. Calcd. for $\mathrm{C}_{14} \mathrm{H}_{20} \mathrm{O}_{3}: \mathrm{C}, 71.16$; $\mathrm{H}, 8.53 \%$. $\nu_{\max } \sim 3400 \sim 2600,1690,1640,1290 \mathrm{~cm}^{-1}$. After standing in a refrigerator it partly crystallized. The semisolid mass was triturated with pet. ether and the crystals were collected by filtration. The pure XIX weighed $8.7 \mathrm{~g}$ (13.8\%). This was recrystallized from ether-pet. ether to give leaflets, $m p 78 \sim 79^{\circ} \mathrm{C}$. Anal. Found: $\mathrm{C}, 71.21 ; \mathrm{H}, 8.47$. Calcd. for $\mathrm{C}_{14} \mathrm{H}_{20} \mathrm{O}_{3}$ : C, 71.16; H, 8.53\%. $\nu_{\max } \sim 3300-\sim 2600,1702,1685$, $1640,1260, \sim 935 \mathrm{~cm}^{-1} ; \delta 1.62(3 \mathrm{H}, \mathrm{s}), 1.67(3 \mathrm{H}, \mathrm{s})$, 4.64 ( $1 \mathrm{H}$, broad), 5.01 ( $1 \mathrm{H}$, broad), $11.29(1 \mathrm{H}, \mathrm{s})$ ppm. The mother liquor $(34 \mathrm{~g})$ after removal of the crystalline XIX was dissolved in $95 \% \mathrm{EtOH}(100 \mathrm{ml})$ and mixed with a soln of semicarbazide hydrochloride $(30 \mathrm{~g})$ and $\mathrm{KOAc}(28 \mathrm{~g})$ in water $(100 \mathrm{ml})$. The $\mathrm{mix}-$ ture was heated under refux for $30 \mathrm{~min}$. The separated semicarbazone was collected on a filter and washed with ether to give $13.2 \mathrm{~g}$ of crystals. Recrystallization from EtOH gave small prisms, mp $196 \sim 198^{\circ} \mathrm{C}$. Anal. Found: $\mathrm{C}, 61.69 ; \mathrm{H}, 7.94 ; \mathrm{N}, 14.48$. Calcd. for $\mathrm{C}_{15} \mathrm{H}_{23} \mathrm{O}_{3} \mathrm{~N}_{3}: \mathrm{C}, 61.41 ; \mathrm{H}, 7.90 ; \mathrm{N}, 14.33 \%$. $\nu_{\max } 3470$, $\sim 3200-\sim 2600,1690,1650,1580,1260, \sim 950 \mathrm{~cm}^{-1}$. The same semicarbazone was also obtained from pure XIX.

4-Methylpent-3-enyl 4'-carbomethoxycyclohex-3'-enyl ketone $(X X)$. The crystalline XIX $(8.2 \mathrm{~g})$ was esterified with $\mathrm{CH}_{2} \mathrm{~N}_{2}$ and the product was distilled in vacuo to give $8.2 \mathrm{~g}(94, \%)$ of $\mathrm{XX}$. An analytical sample boiled at $150 \sim 153^{\circ} \mathrm{C} / 1.8 \mathrm{~mm}, n_{\mathrm{D}}^{19} 1.4950$. Anal. Found: $\mathrm{C}_{3}$ 71.93; H, 8.84. Calcd. for $\mathrm{C}_{15} \mathrm{H}_{22} \mathrm{O}_{3}: \mathrm{C}, 71.97 ; \mathrm{H}$, $8.86 \% . \quad \nu_{\max } 1730(\mathrm{sh}), 1715,1654,1622,1250,1075$, $1035,915 \mathrm{~cm}^{-1} ; \delta 1.58(3 \mathrm{H}, \mathrm{s}), 1.63(3 \mathrm{H}, \mathrm{s}), 3.63$ ( $3 \mathrm{H}, \mathrm{s}), 4.98$ ( $1 \mathrm{H}$, broad), 6.89 (1 H, broad) ppm.

4-Methylpent-3-enyl 4'-carbomethoxycyclohex-3'-enyl ketone ethylene ketal $(X X I)$. To a soln of XX $(7.0 \mathrm{~g})$ in anhyd 1,2-dichloroethane $(100 \mathrm{ml})$ ethylene glycol $(6 \mathrm{ml})$ and $p$-TsOH $(0.1 \mathrm{~g})$ were added and the mixture stirred and heated for $2 \mathrm{hr}$. During that period anhyd 1,2-dichloroethane (ca. $300 \mathrm{ml}$ ) was gradually added while an equal amount of the water-containing solvent was distilled off from it. After cooling, the 
soln was washed with $\mathrm{K}_{2} \mathrm{CO}_{3}$ aq, dried over $\mathrm{K}_{2} \mathrm{CO}_{3}$ and concentrated. The residue was distilled in vacuo to give $5.4 \mathrm{~g}(65 \%)$ of XXI, bp $150 \sim 165^{\circ} \mathrm{C} / 0.1 \mathrm{~mm}$. An analytical sample boiled at $160 \sim 165^{\circ} \mathrm{C} / 0.1 \mathrm{~mm}$, $n_{\mathrm{D}}^{23}$ 1.4960. Anal. Found: C, 69.50; H, 8.90. Calcd. for $\mathrm{C}_{17} \mathrm{H}_{26} \mathrm{O}_{4}: \quad \mathrm{C}, 69.36 ; \mathrm{H}, 8.90 \%$. $\nu_{\max } 1718,1655$, $1250,1080,1042,940,720 \mathrm{~cm}^{-1} ; \delta 1.55(3 \mathrm{H}, \mathrm{s}), 1.62$ ( $3 \mathrm{H}, \mathrm{s}), 3.56(3 \mathrm{H}, \mathrm{s}), 3.80(4 \mathrm{H}, \mathrm{s}), 4.95$ (1 H, broad), 6.75 (1 H, broad) ppm.

4-Methylpent-3-enyl 4'-hydroxymethylcyclohex-3'-enyl ketone ethylene ketal $(X X I)$. A soln of XXI $(5.3 \mathrm{~g})$ in ether $(50 \mathrm{ml})$ was added dropwise to a suspension of LAH $(1.8 \mathrm{~g})$ in ether $(50 \mathrm{ml})$. The mixture was stirred at room temp for $5 \mathrm{hr}$. Then the excess hydride was destroyed by the addition of EtOAc. Dilute $\mathrm{H}_{2} \mathrm{SO}_{4}$ (6 $\mathrm{ml}$ conc $\mathrm{H}_{2} \mathrm{SO}_{4}+50 \mathrm{ml} \mathrm{H}_{2} \mathrm{O}$ ) was added to the mixture. After stirring for $10 \mathrm{~min}$ at room temp, the ether layer was separated and the aqueous layer was extracted with ether. The combined ethereal soln was washed with sat $\mathrm{NaCl}$ aq, dried $\left(\mathrm{MgSO}_{4}\right)$ and concentrated to give $4.6 \mathrm{~g}(94 \%)$ of oily XXII. An analytical sample boiled at $160 \sim 162^{\circ} \mathrm{C} / 0.1 \mathrm{~mm}, n_{\mathrm{D}}^{19}$ 1.5032. Anal. Found: C, 72.29; H, 10.12. Calcd. for $\mathrm{C}_{16} \mathrm{H}_{26} \mathrm{O}_{3}: \quad \mathrm{C}, 72.14 ; \mathrm{H}, 9.84 \%$. v $\nu_{\text {max }} 3360,1680$ (w), $1660(w), 1045 \mathrm{~cm}^{-1} ; \delta 1.56(3 \mathrm{H}, \mathrm{s}), 1.64(3 \mathrm{H}$, s), $3.36(1 \mathrm{H}$, broad), $3.76(2 \mathrm{H}, \mathrm{s}), 3.82(4 \mathrm{H}, \mathrm{s})$, $5.00(1 \mathrm{H}, \mathrm{m}), 5.51$ (1 H, broad) ppm.

4-Methylpent-3-enyl 4'-acetoxymethylcyclohex-3'-enyl ketone $(X X I I)$. A soln of XXII $(4.5 \mathrm{~g})$ in pyridine (25 ml) was mixed with $\mathrm{Ac}_{2} \mathrm{O}(25 \mathrm{ml})$ and left to stand overnight at room temp. The mixture was concentrated in vacuo. The residue was acidified with dil $\mathrm{HCl}$ and heated for $5 \mathrm{~min}$ on a boiling water bath. After cooling, the mixture was extracted with ether. The extract was washed with $\mathrm{NaHCO}_{3}$ aq and sat $\mathrm{NaCl}$ aq, dried $\left(\mathrm{MgSO}_{4}\right)$ and concentrated to give $4.1 \mathrm{~g}(9196)$ of oily XXIII. An analytical sample boiled at $142 \sim 145^{\circ} \mathrm{C} / 0.1 \mathrm{~mm}, n_{\mathrm{D}}^{20} 1.4850$. Anal. Found: C, 72.53; $\mathrm{H}$, 9.13. Calcd. for $\mathrm{C}_{16} \mathrm{H}_{24} \mathrm{O}_{3}$ : C, 72.69; $\mathrm{H}, 9.15 \%$. $\nu_{\max } 1730,1710,1220,1015 \mathrm{~cm}^{-1} ; \delta 1.59$ ( $3 \mathrm{H}, \mathrm{s}), 1.65(3 \mathrm{H}, \mathrm{s}), 1.96(3 \mathrm{H}, \mathrm{s}), 4.30(2 \mathrm{H}, \mathrm{s})$, $4.95(1 \mathrm{H}, \mathrm{m}), 5.63(1 \mathrm{H}$, broad s) ppm.

2-(4'-Acetoxymethylcyclohex-3'-enyl)-6-methylhepta-1, 5diene $(X X I V)$. To a soln of sodium methylsulfinyl methylide (from $200 \mathrm{mg}$ of $50 \% \mathrm{NaH}$ ) in DMSO (25 $\mathrm{ml}$ ) was added triphenylmethylphosphonium bromide $(2.6 \mathrm{~g})$ under $\mathrm{N}_{2}$ with ice-cooling. The mixture was stirred for $10 \mathrm{~min}$ to yield an orange-red soln of the
Wittig reagent. A soln of XXIII ( $\mathrm{lg}$ ) in DMSO (4 ml) was added to the reagent. The mixture was stirred for $3 \mathrm{hr}$ at room temp, poured into ice-water and extracted with $n$-hexane. The extract was washed with $80 \%$ $\mathrm{MeOH}$ aq, dried($\left(\mathrm{MgSO}_{4}\right)$ and concentrated in vacuo to give $0.8 \mathrm{~g}(80 \%)$ of XXIV. An analytical sample boiled at $128 \sim 130^{\circ} \mathrm{C} / 0.1 \mathrm{~mm}, n_{\mathrm{D}}^{20} 1.4884$. Anal. Found: C, 77.99; $\mathrm{H}$, 9.79. Calcd. for $\mathrm{C}_{17} \mathrm{H}_{26} \mathrm{O}_{2}$ : C, 77.82; $\mathrm{H}, 9.99 \%$. $\nu_{\max } 3070,2920,1742,1645,1430,1370$, $1220,1015,954,880 \mathrm{~cm}^{-1} ; \delta 1.58(3 \mathrm{H}, \mathrm{s}), 1.66(3 \mathrm{H}$, s), $1.97(3 \mathrm{H}, \mathrm{s}), 4.30(2 \mathrm{H}, \mathrm{s}), 4.66(2 \mathrm{H}, \mathrm{s}), 5.00$ (1 H, m), $5.63(1 \mathrm{H}$, broad) ppm.

2-(4'-Hydroxymethylcyclohex-3'-enyl)-6-methylhepta-1, 5diene $(X X V)$. A soln of XXIV (2.9 g) in $\mathrm{MeOH}(20$ $\mathrm{ml}$ ) was mixed with $\mathrm{KOH}(1 \mathrm{~g})$ in $\mathrm{MeOH}(10 \mathrm{ml})$ and left to stand overnight at room temp. The mix* ture was concentrated in vacuo, diluted with water and extracted with ether. The extract was washed with sat $\mathrm{NaCl}$ aq, dried $\left(\mathrm{MgSO}_{4}\right)$ and concentrated to give $2.3 \mathrm{~g}(94,6)$ of XXV. An analytical sample boiled at $125^{\circ} \mathrm{C} / 0.06 \mathrm{~mm}, n_{\mathrm{D}}^{20} 1.5030$. Anal. Found: C, 81.20: H, 11.05. Calcd. for $\mathrm{C}_{15} \mathrm{H}_{24} \mathrm{O}: \mathrm{C}, 81.76$ : H, 10.98\%. $\nu_{\max } \sim 3300,3080,2900,1640,1430,1370$, $1050,980,910,880,820 \mathrm{~cm}^{-1} ; \delta 1.58(3 \mathrm{H}, \mathrm{s}), 1.65$ ( $3 \mathrm{H}, \mathrm{s}), 2.01$ (broad s), $3.30(1 \mathrm{H}$, broad), $3.76(2 \mathrm{H}$, s), $4.64(2 \mathrm{H}, \mathrm{s}), 5.00(1 \mathrm{H}$, broad), $5.53(1 \mathrm{H}$, broad s) ppm.

2-(4'-Formylcyclohex -3'-enyl)-6-methylhepta-1, 5-diene $(X X V I)$. To a soln of crude XXV $(2.2 \mathrm{~g})$ in $n$-hexane $(100 \mathrm{ml})$ was added $\mathrm{MnO}_{2}(12 \mathrm{~g})$. The mixture was stirred under $\mathrm{N}_{2}$ for $23 \mathrm{hr}$ at room temp and then filtered. The filtrate was concentrated in vacuo. The residue boiled at $114 \sim 115^{\circ} \mathrm{C} / 0.05 \mathrm{~mm}$ to give $1.7 \mathrm{~g}$ $(77 \%)$ of XXVI, $n_{\mathrm{D}}^{19}$ 1.5085. Anal. Found: C, 81.85; $\mathrm{H}, 9.94$. Calcd. for $\mathrm{C}_{15} \mathrm{H}_{22} \mathrm{O}: \mathrm{C}, 82.51 ; \mathrm{H}, 10.16 \%$. $\nu_{\max } 3080,2900,2720,1685,1648,1158,882,765 \mathrm{~cm}^{-1}$; $\delta 1.60(3 \mathrm{H}, \mathrm{s}), 1.66(3 \mathrm{H}, \mathrm{s}), 2.05$ (broad s), 4.70 $(2 \mathrm{H}, \mathrm{s}), 5.00(1 \mathrm{H}, \mathrm{m}), 6.65(1 \mathrm{H}, \mathrm{m}), 9.33(1 \mathrm{H}, \mathrm{s})$ ppm.

2-(4'-Carbomethoxycyclohex-3'-enyl) -6 -methylhepta-1, 5diene $(I I I)$. A soln of XXVI $(500 \mathrm{mg})$ in $\mathrm{MeOH}$ $(50 \mathrm{ml})$ was mixed with $\mathrm{MnO}_{2}(5.75 \mathrm{~g})$, NaCN $(820$ $\mathrm{mg})$ and $\mathrm{AcOH}(0.3 \mathrm{ml})$. The mixture was stirred overnight at room temp and then filtered. The filtrate was concentrated in vacuo, diluted with water and extracted with ether. The ethereal soln was washed with water and sat $\mathrm{NaCl}$ aq, dried $\left(\mathrm{MgSO}_{4}\right)$ and concentrated in vacuo to give III $(400 \mathrm{mg}, 73 \%)$. An 
analytical sample boiled at $134 \sim 136^{\circ} \mathrm{C} / 0.1 \mathrm{~mm}, n_{\mathrm{D}}^{20}$ 1.4922. Anal. Found: C, 77.06; H, 9.92. Calcd. for $\mathrm{C}_{16} \mathrm{H}_{24} \mathrm{O}_{2}: \quad \mathrm{C}, 77.37 ; \mathrm{H}, 9.74 \%$. $\nu_{\max } 3070,2910$, $1715,1640,1425,1370,1295,1240,1190,1075,1030$, $880 \mathrm{~cm}^{-1} ; \delta 1.58(3 \mathrm{H}, \mathrm{s}), 1.66(3 \mathrm{H}, \mathrm{s}), 3.60(3 \mathrm{H}, \mathrm{s})$, $4.68(2 \mathrm{H}, \mathrm{s}), 5.00(1 \mathrm{H}$, broad $), 6.85(1 \mathrm{H}$, broad $) \mathrm{ppm}$.

4-Chloro-4-methylpentyl 4'-carbomethoxycyclohex-3'-enyl ketone $(X X V I I)$. An ice-cooled soln of XX (0.3 g) in $\mathrm{MeOH}(10 \mathrm{ml})$ was saturated with dry $\mathrm{HCl}$ gas, left to stand for $30 \mathrm{~min}$ at $0 \sim 5^{\circ} \mathrm{C}$ and then poured into ice-water. The mixture was extracted with pet. ether. The extract was washed with water and sat $\mathrm{NaCl} \mathrm{aq}$, dried $\left(\mathrm{MgSO}_{4}\right)$ and concentrated in vacuo to give $0.3 \mathrm{~g}$ of XXVII. $\nu_{\max } 1710,1650,1255,1090$ $\mathrm{cm}^{-1} ; \delta 1.55(6 \mathrm{H}, \mathrm{s}), 3.61(3 \mathrm{H}, \mathrm{s}), 6.80$ (1 H, broad) ppm. This could not be purified because of its instability.

2-(4'-Carbomethoxycyclohex-3'-enyl)-2,6-dichloro-6-methylheptane (XXVIIII). An ice-cooled soln of III $(0.2 \mathrm{~g})$ in $\mathrm{MeOH}(6 \mathrm{ml})$ was saturated with dry $\mathrm{HCl}$ gas, left to stand for $30 \mathrm{~min}$ at $0 \sim 5^{\circ} \mathrm{C}$ and then poured into ice-water. The mixture was extracted with pet. ether. The extract was washed with water and sat $\mathrm{NaCl}$ aq, dried $\left(\mathrm{MgSO}_{4}\right)$ and concentrated in vacuo to give $0.2 \mathrm{~g}$ of XXVIII. $\nu_{\max } 1710,1650,1255$, 1085, $1035 \mathrm{~cm}^{-1} ; \delta 1.55(9 \mathrm{H}, \mathrm{s}), 3.61(3 \mathrm{H}, \mathrm{s}), 6.79$
( $1 \mathrm{H}$, broad) ppm. This could not be purified because of its instability.

Bioassay. Data are based on topical treatment of last instar nymphs of Pyrrhocoris apterus. (10 insects per assay)

\begin{tabular}{rcccc} 
& & & \multicolumn{2}{c}{ Dosage $(\mu \mathrm{g})$} \\
Compound & 0.01 & 0.1 & 1.0 & 10.0 \\
XX & $\mathrm{A}$ & $\mathrm{A}$ & $\mathrm{A}$ & $\mathrm{NA}$ \\
III & $\mathrm{A}$ & $\mathrm{A}$ & $\mathrm{A}$ & $\mathrm{A}+\mathrm{NC}$ \\
XXVII & $\mathrm{A}$ & $\mathrm{A}$ & $\mathrm{A}$ & $\mathrm{A}+\mathrm{NC}$ \\
XXVIII & $\mathrm{A}$ & $\mathrm{A}$ & $\mathrm{A}+\mathrm{NC}$ & $\mathrm{SN}$
\end{tabular}

$A=$ Normal adults (no activity).

$\mathrm{A}+\mathrm{NC}=$ Adults with nymphal cuticle on the abdomen (very little activity).

$\mathrm{NA}=$ Nymphal-adult intermediate (intermediate activity).

$\mathrm{SN}=$ Supernumerary nymphs (high activity).

Acknowledgements. Our thanks are due to Dr. W.S. Bowers, USDA Agricultural Research Service, Beltsville, U.S.A., for bioassay. A gift of $\alpha$-acetyl- $\gamma$ butyrolactone, employed for the preparation of 4methylpent-3-enyl bromide, by Daicel Co., Tokyo is gratefully acknowledged. 